\title{
Air pollution - Induced biochemical changes in some plants in selected forest reserves in Edo State, Nigeria
}

\author{
Agbaire, P. O. ${ }^{1 *}$, Akporhonor, E. E. ${ }^{1}$ and Ogboru R. O. $^{2}$ \\ ${ }^{1}$ Department of Chemistry, Delta State University, P.M.B, 1, Abraka, Delta State, Nigeria. \\ ${ }^{2}$ Research Coordinating Unit, Forestry Research Institute of Nigeria, P.M.B 5087, Jericho Hills, Ibadan, Oyo state, \\ Nigeria. \\ *Corresponding author. Email: agbaire@delsu.edu.ng, patagbaire@gmail.com
}

Copyright (@ 2017 Agbaire et al. This article remains permanently open access under the terms of the Creative Commons Attribution License 4.0, which permits unrestricted use, distribution, and reproduction in any medium, provided the original work is properly cited.

Received 8th September, 2017; Accepted 20th November, 2017

\begin{abstract}
Air pollution has been reported to induce biochemical changes in plants leaves. This study determined the effect of air pollution on chlorophyll $a$ and $b$ and carotenoids of leaf samples from three forest reserves in Edo state, Nigeria. The leaves of the plants were collected from mature trees and used to determine the values of Chlorophyll a, Chlorophyll $b$ and carotenoid using standard methods of analysis. Ogba Forest was found to be lowest in both chlorophyll-a and b in Dacryodes edulis $(5.00 \pm 12.0 \mathrm{mg} / 100 \mathrm{~g})$ and Moringa oleifera $(20.09 \pm 12.72 \mathrm{mg} / 100 \mathrm{~g})$. Chlorophylla was, however, highest in Hura crepitans $(16.78 \pm 32.45 \mathrm{mg} / 100 \mathrm{~g})$ while chlorophyll-b was highest in Dacryodes edulis $(46.25 \pm 8.97 \mathrm{mg} / 100 \mathrm{~g})$. While UNIBEN forest reserve recorded the lowest chlorophyll-a value in Moringa oleifera $(4.42 \pm 24.93 \mathrm{mg} / 100 \mathrm{~g})$ and exhibited lowest value of chlorophyll-b in Albiza labbek $(10.33 \pm 35.69 \mathrm{mg} / 100 \mathrm{~g})$. Saponba forest reserve recorded lowest chlorophyll-a in Magnifera indica $(7.05 \pm 11.48 \mathrm{mg} / 100 \mathrm{~g})$, it was however, highest in Irvinga garbonesis (14.61 $\pm 18.14 \mathrm{mg} / 100 \mathrm{~g})$. Its value in chlorophyll-b, however, ranged from $12.66 \pm 1.68$ to $31.05 \pm 20.14$ $\mathrm{mg} / 100 \mathrm{~g}$. Same trend was observed with the carotenoid contents across board. Ogba forest reserve indicated the lowest value from Dacryodes edulis $(6.72 \pm 6.73 \mathrm{mg} / 100 \mathrm{~g})$, it was highest in Hura crepitans $(23.86 \pm 7.84 \mathrm{mg} / 100 \mathrm{~g}$ ). UNIBEN forest reserve recorded lowest in Magnifera indica $(3.10 \pm 0.37 \mathrm{mg} / 100 \mathrm{~g})$ and highest in Dacryodes edulis $(21.73 \pm 15.11 \mathrm{mg} / 100 \mathrm{~g})$. Saponba forest reserve was not different in trend, as its lowest value was recorded in Entadrophragma angolensis $(0.04 \pm 2.23 \mathrm{mg} / 100 \mathrm{~g})$ and highest in Magnifera indica $(11.17 \pm 3.20 \mathrm{mg} / 100 \mathrm{~g})$. Species lowest in both chlorophyll-a and $b$ and carotenoids are therefore more susceptible to the impact of air pollution in their respective forest reserves.
\end{abstract}

Key words: Air pollution, chlorophyll-a, chlorophyll-b, carotenoid, forest reserves.

\section{INTRODUCTION}

Chlorophyll, being the pigment that gives plants and algae their green colour, it is solitary, vital and the most abundant photosynthetic pigments (Tripathi and Gautam, 2007). Biochemical parameters which include chlorophyll and carotenoids found in plants are responsible for such plants to be used as bio-monitors and bio-mitigators in the environment and it is more cost effective (Kapoor and Chittora, 2016). Chlorophyll is required for the efficiency and wellbeing of plants (Dash and Curran, 2007). Chlorophyll molecules are arranged specifically in and around photosystems, embedded in the thylakoid membranes of chloroplasts and plays a significant role in photosynthesis (Rai et al., 2009; Penuelas et al, 1993). Chlorophyll, is however, one of the indices of photosynthetic activity (Larcher, 1995), although leaf chlorophyll content fluctuates within wide limits (from 0.05 to $0.30 \%$ of fresh matter). Available reports indicate that the ratio amid chlorophylls $a$ and $b$ is $3: 1$ (Gross, 1991). These values vary as a function of plant growth and development, the cultivar of plant in question and a number of environmental factors. The maximum chlorophyll content in plants follows at the outset of the 
flowering phase, and chlorophyll is believed to take part in the process of organogenesis (Sims and Gamon, 2002). There is usually a minimum 4 to $5 \mathrm{mg}$ of chlorophyll per unit of leaf surface (Anamaria, 2015). The colour of the leaves of certain cultivars and varieties are not always directly interrelated with chlorophyll concentration (Joshi and Swami, 2009).

Carotenoids are natural isoprenoid pigments responsible for distinctive yellow, orange and some reddish colors of leaves, fruits, vegetables and flowers as well as several aromas in plants. Their sunny colours function as attractants for pollination and seed dispersal (Jenson, 1978). Carotenoid comprises a large family of C40 polyenes and is created by all photosynthetic creatures (Cuttris et al., 2011). Carotenoids are essential agriculture, food, health and the cosmetic industries. In plants, carotenoids are essential components required for photosynthesis, photo-protection and the production of carotenoid-derived phyto-hormones, including ABA (Abscisic acid) and strigolactone. Biosynthesis of carotenoids in plants is a genetic representative, but environmental circumstances also have an important part.

The strength of tint, its dimness and the allure of the plant pigment depend on the level of chlorophyll pigments and its amounts (Lisiewska et al., 2001). In green plants the chlorophyll pigments are accompanied by carotenoids, which affect the colour of the raw material and of products obtained from it. They also enhance their vitamin content. Chlorophyll is an indicator of productivity of plant (Raza and Murthy, 1998). Some particular pollutants are responsible for the increase or decrease of chlorophyll content. The similar impact of air pollutants in the chlorophyll contents have been reported by a number of other works (Tripathi and Gautam, 2007; lqbal et al., 2015; Mate and Deshmukh, 2016; Giri et al., 2013.

Chlorophylls and carotenoids are very important pigments of developed plant absorptive materials and responsible for modification of color from dark-green to yellow. However, they play vital roles in photosynthetic processes and utilizing light energy which is transformed into chemical energy (Nayek et al., 2014). Through the process of photosynthesis, chlorophylls transmit radiant energy of sunlight into the chemical energy of organic carbon compounds in the cell (Viscas et al., 2010). The fraction of chlorophyll and carotenoid tint content is strongly correlates with photosynthetic functioning of vegetation (Lisiewska et al., 2006) and this capacity varies in a range of environmental conditions. This study was aimed at evaluating the levels of Chlorophyll-a, Chlorophyll-b and Carotenoids in the selected tree species from three forest reserves: The Ogba, University of Benin and Saponba Forest Reserves located in EdoState, Nigeria. The objective was to also investigate differences in Chlorophyll-a, Chlorophyll-b and Carotenoids in selected trees species from three forest reserves.

\section{METHODOLOGY}

\section{Study area}

The study sites were:

1. Saponba Forest Reserve: This forest reserve lies within the latitude $06^{\circ} 25^{\prime} 32^{\prime \prime} \mathrm{N}$ and longitude $05^{\circ}$ 5 '28" $E$ and covers an expanse of $521 \mathrm{~km}^{2}$ in the rain forest zone.

2. University of Benin Forest Reserve: The University of Benin study site is located inside the eastern part of the main campus of the University of Benin, Ugbowo Campus. The site falls within Latitude $6^{0} 24^{1}$ $20.9^{11} \mathrm{~N}$ and Longitude $5^{0} 38^{1} 52^{11} \mathrm{E}$.

3. Ogba Forest Reserve: Ogba Forest Reserve is located in Oredo Local government area of Edo state, Nigeria. The reserve lies between Longitude $6^{0} 19^{1} \mathrm{~N}$ and Latitude $5^{0} 41^{1} \mathrm{E}$.

\section{Samples collection}

Ten (10) plant species located within the selected forest reserves in Edo state, Nigeria were investigated (Table 1) $>$ These samples were authenticated by the taxonomist of the Department of Forestry, University of Benin, $\mathrm{Mr}$ F.E. Osayimnwen. Leaf Samples were collected from mature tree in triplicates for a six month period (between 7 to $8 \mathrm{am}$ ) of the morning. The trees were marked and the leaves samples were obtained from the same trees during the six month period. Fresh samples were put in coolers and brought to the Laboratory for analysis.

\section{Determination of total chlorophyll and carotenoid content}

Total Chlorophyll and carotenoid content were measured as described by Agbaire and Esiefarienrhe (2009), Lichtentaler (1985) and Wellburn (1994). $3 \mathrm{~g}$ of the fresh leaves sample was weighed, mixed and mined with $10 \mathrm{ml}$ of $80 \%$ acetone each. It was allowed to stand still for about 15 minutes for thorough extraction. The liquid portion was filtered using filter paper into another test tube and centrifuged at $2500 \mathrm{pm}$ for 3 minutes. The supernatant was collected and the absorbance was read at 645 and $662 \mathrm{~nm}$ for chlorophyll $a$ and $b$ and $470 \mathrm{~nm}$ for carotenoids respectively using a spectrophotometer with Model 752. Equations used for calculation are presented below:

$$
\begin{aligned}
& \text { Chlorophyll-a }=11.75 \mathrm{~A} 662-2.350 \mathrm{~A} 645 \\
& \text { Chlorophyll-b }=18.61-3.960 \mathrm{~A} 662 \\
& \text { Carotene }=1000 \mathrm{~A} 470-2.270 \mathrm{Chl} \mathrm{a}+\frac{81.4 \mathrm{Chl} \mathrm{b}}{227}
\end{aligned}
$$


Table 1. Trees species sited within the selected forest reserves in Edo state, Nigeria.

\begin{tabular}{cll}
\hline Species No & Scientific Names & Common Names \\
\hline 1 & Albizia lebbek & Flea tree \\
2 & Irvinga garbonesis & Sweet Ogbolor \\
3 & Entadrophragma angolensis & \\
4 & Azadirachta indica & Neem tree \\
5 & Hura crepitans & Sandbox tree \\
6 & Dacryodes edulis & African pear \\
7 & Psidium guajava & Guava \\
8 & Citrus cenesis & Orange \\
9 & Mangifera indica & Mango \\
10 & Moringa Olifera & Moringa \\
\hline
\end{tabular}

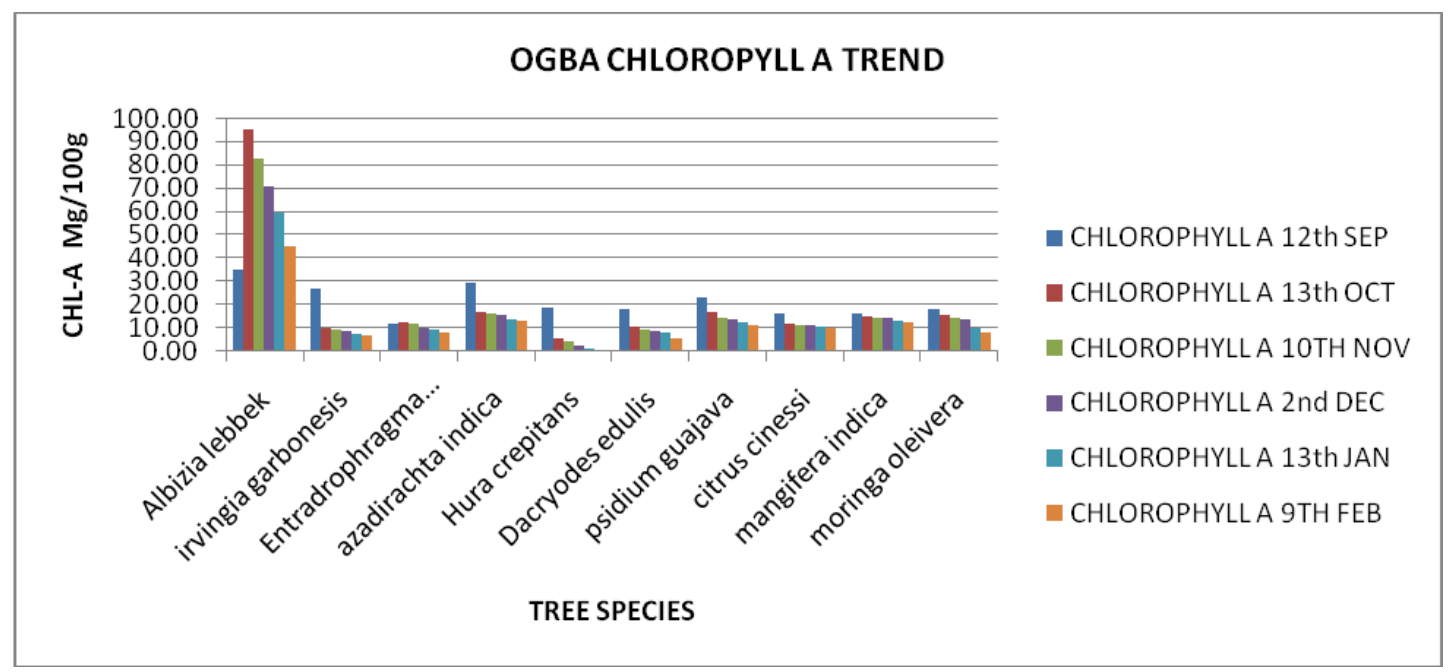

Figure1.Chlorophyll-a trend for Ogba Forest Reserve.

All Measurements were done in triplicates. Table 5 represents the ANOVA results for Chlorophyll-a, Chlorophyll-b and Carotenoid analyzed for in this study. Statistically, it revealed that there were significant differences in the means of Chlorophyll-a $(p \leq 0.05)$, Chlorophyll-b $(p \leq 0.05)$ and Carotenoid $(p \leq 0.05)$.

\section{RESULT AND DISCUSSION}

\section{Chlorophyll-a}

Chlorophyll-a is found to be more responsive to gaseous pollutants like $\mathrm{SO}_{2}$ than chlorophyll-b (kaapor and Chittora, 2016) in the Ogba Forest Reserve. The lowest value of Chlorophyl-a was obtained from Dacryodes edulis with a value of $5.00 \pm 12.60 \mathrm{mg} / 100 \mathrm{~g}$ and highest obtained from Hura crepitans with a value of $16.78 \pm 32.45$ $\mathrm{mg} / 100 \mathrm{~g}$. Figures 1,2 and 3 shows the various trend for the values obtained in Table 2. In UNIBEN forest Reserve, the lowest value obtained was from Moringa oleifera with a value of $4.42 \pm 14.93 \mathrm{mg} / 100 \mathrm{~g}$ and the highest obtained was from Albiza lebbek with a value of $25.42 \pm 24.93 \mathrm{mg} / 100 \mathrm{~g}$. From the Saponba Forest, the lowest value for Chlorophyll-a obtained was $7.05 \pm 11.48$ $\mathrm{mg} / 100 \mathrm{~g}$ Magnifera indica tree species and highest was from Irvinga garbonesis with a value of $14.61 \pm 18.14$ $\mathrm{mg} / 100 \mathrm{~g}$. The result in Table 2 show the lowest chlorophyll-a value is Moringa olifera found in UNIBEN forest reserve with a value of $4.42 \pm 14.93 \mathrm{mg} / 100 \mathrm{~g}$. This could mean that the forest reserve is uncovered to elevated ambient air pollution load (Agbaire et al., 2016). Sulphur dioxide $\left(\mathrm{SO}_{2}\right)$, Nitrogen Oxides and $\mathrm{CO}_{2}$ along with perched particulate matter, when absorbed by the leaves may cause a reduction in the concentration of photosynthetic pigments like Chlorophyll-a, Chlorophyll-b and Carotenoids. This may directly affect the plant productivity (Joshi and Swami, 2009). A sizeable loss in 


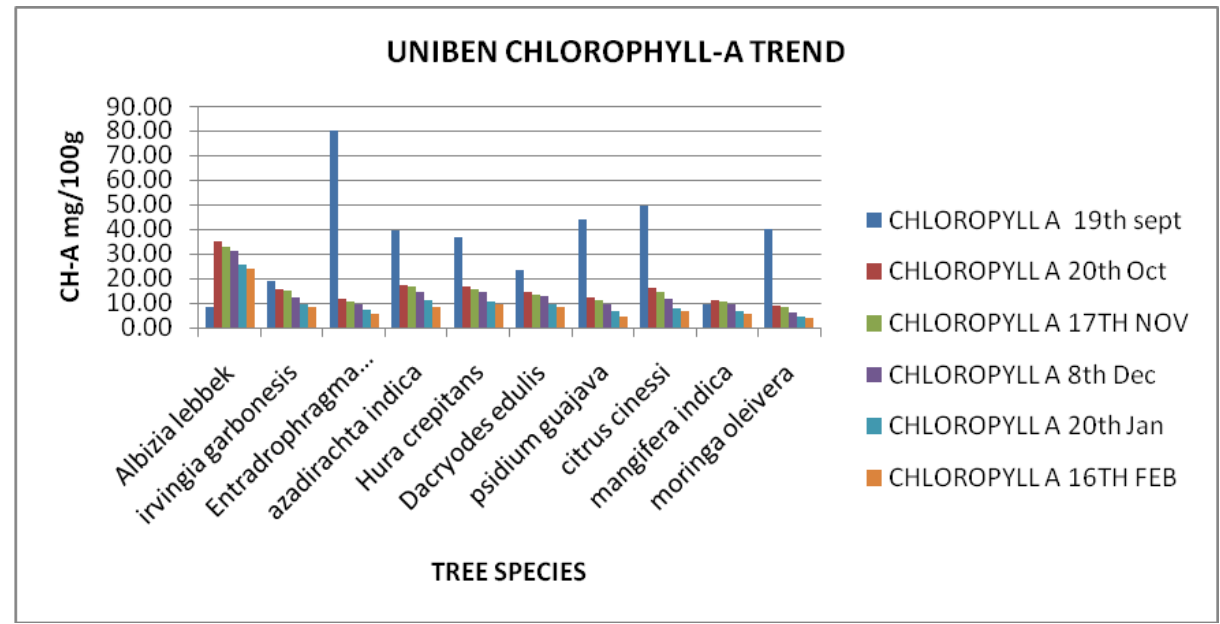

Figure 2. Chlorophyll-a trend for UNIBEN Forest Reserve.

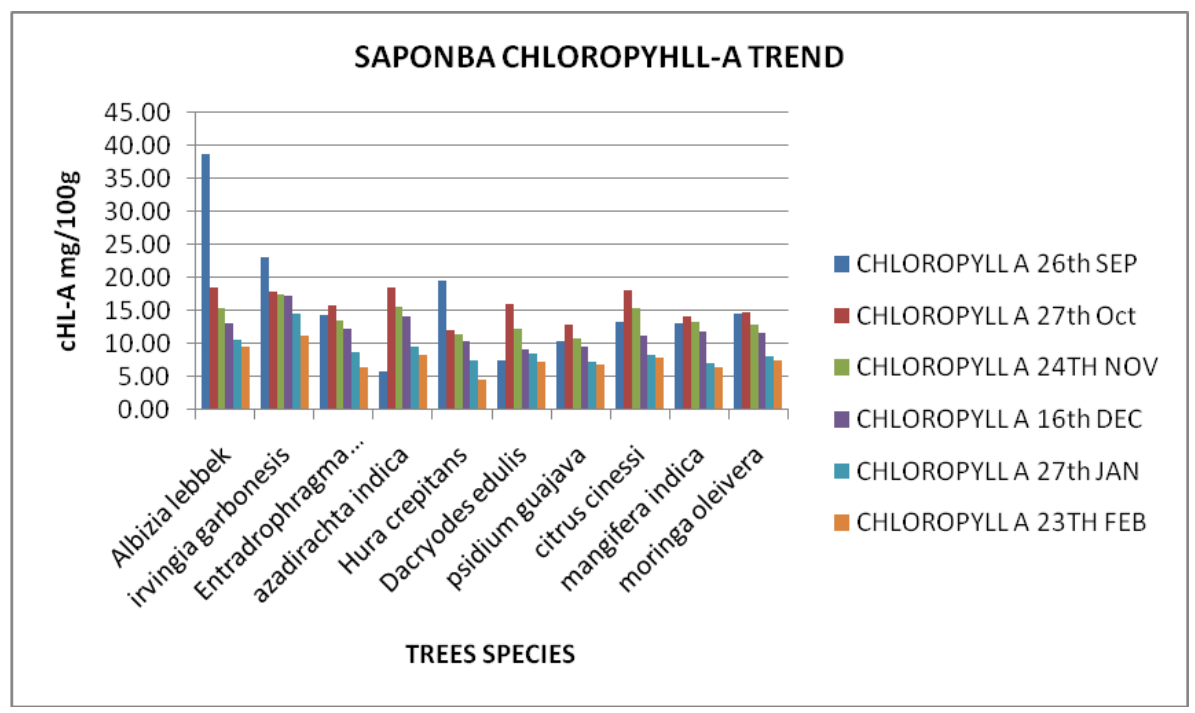

Figure 3. Chlorophyll-a trend for Saponba Forest Reserve.

Table 2. Chlorophyll-a values during study in the three locations in $\mathrm{mg} / 100 \mathrm{~g}$.

\begin{tabular}{llccc}
\hline $\mathbf{S} / \mathbf{N}$ & Tree species & Ogba & UNIBEN & Saponba \\
\hline 1 & Albizia lebbek & $13.52 \pm 16.05$ & $25.42 \pm 24.93$ & $10.66 \pm 20.14$ \\
2 & Irvinga garbonesis & $9.31 \pm 11.86$ & $9.36 \pm 13.92$ & $14.61 \pm 18.14$ \\
3 & Entadrophragma angolensis & $8.26 \pm 16.44$ & $6.99 \pm 27.05$ & $8.65 \pm 12.75$ \\
4 & Azadirachta indica & $12.79 \pm 14.86$ & $10.94 \pm 20.57$ & $9.45 \pm 11.92$ \\
5 & Hura crepitans & $16.78 \pm 32.45$ & $10.33 \pm 19.54$ & $7.45 \pm 12.34$ \\
6 & Dacryodes edulis & $5.00 \pm 12.60$ & $9.45 \pm 15.05$ & $8.44 \pm 10.26$ \\
7 & Psidium guajava & $8.62 \pm 11.52$ & $6.85 \pm 18.14$ & $7.30 \pm 10.00$ \\
8 & Citrus cenesis & $12.05 \pm 21.46$ & $7.94 \pm 21.30$ & $8.20 \pm 12.72$ \\
9 & Mangifera indica & $14.13 \pm 13.60$ & $6.45 \pm 9.05$ & $7.05 \pm 11.48$ \\
10 & Moringa Olifera & $12.44 \pm 12.72$ & $4.42 \pm 14.93$ & $8.09 \pm 12.21$ \\
\hline
\end{tabular}

$\pm \mathbf{s d}$, Standard deviation. 


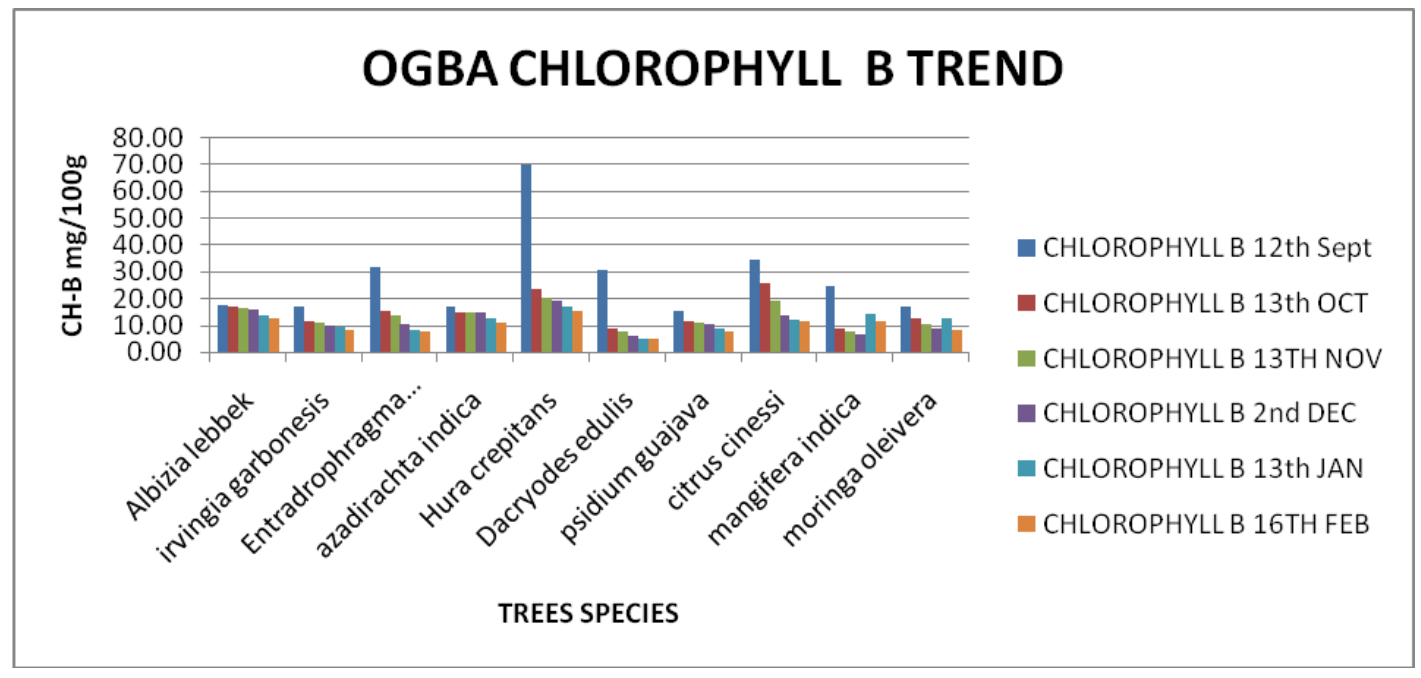

Figure 4. Chlorophyll-b Trend for Ogba Forest Reserve.

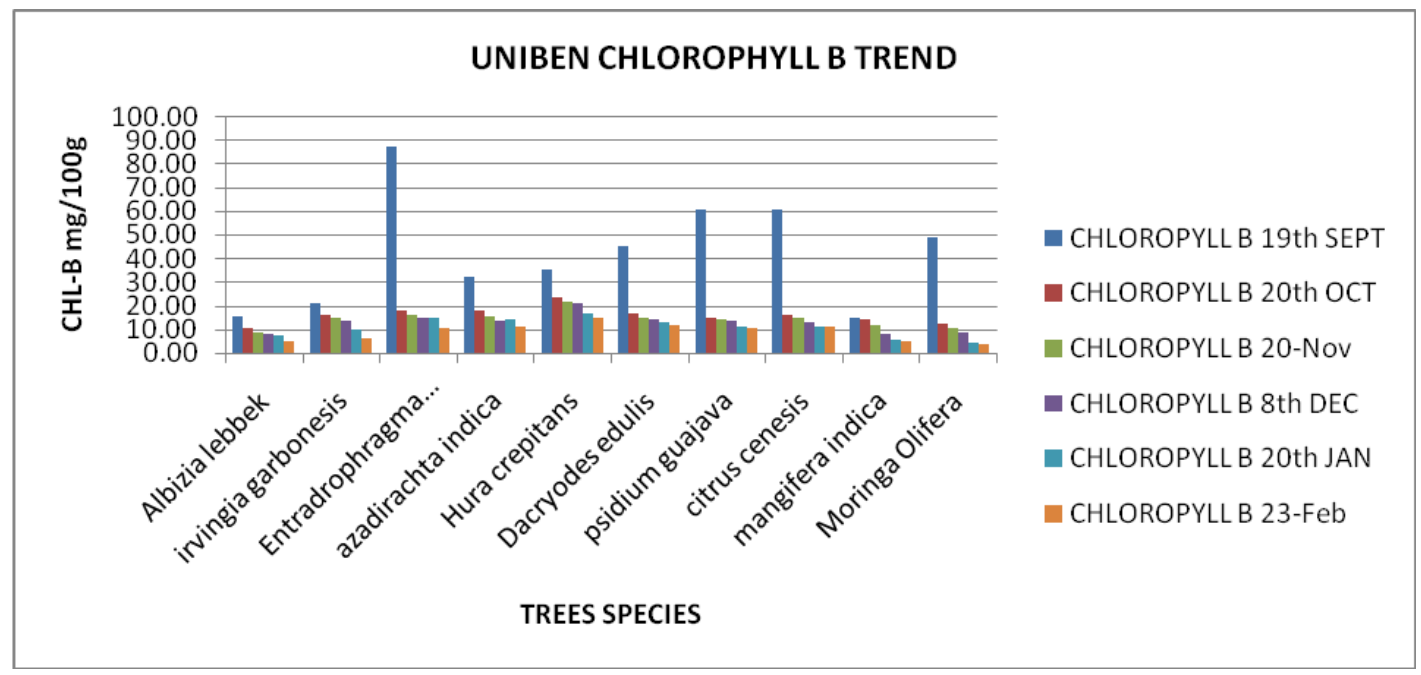

Figure 5. Chlorophyll-b Trend for UNIBEN Forest Reserve.

Chlorophyll-a in the leaves of plants exposed to air pollution stress supports the argument that such trees species are attacked by air pollutants (Tripathi and Gautam, 2007). The chlorophyll level in plants decreases under pollution stress (Kousar et al., 2014). The air gases which exhausts from vehicles shows the bad effects on chlorophyll-a and Chlorophyll-b (Shiragave et al., 2015).

\section{Chlorophyll-b}

Chlorophyll $\mathbf{b}$ is a form of Chlorophyll that helps in photosynthesis by absorbing light energy. It is more soluble than chlorophyll-a in polar solvents because of its carbonyl group. Its colour is yellow and primarily absorbs blue light (David, 2009).

In Ogba Forest Reserve, the lowest value of Chlorophyl-b recorded was $20.09 \pm 12.72 \mathrm{mg} / 100 \mathrm{~g}$ from Moringa oleifera and the highest was from Dacryodes edulis with a value of $46.25 \pm 8.97 \mathrm{mg} / 100 \mathrm{~g}$ (Figure 4). In UNIBEN Forest Reserve, the lowest value obtained was $10.33 \pm 3.77 \mathrm{mg} / 100 \mathrm{~g}$ from Albiza lebbek tree while the highest was obtained from Entadrophragma angolensis with a value of $33.63 \pm 35.69 \mathrm{mg} / 100 \mathrm{~g}$ (Figure 5).

Similarly, Saponba Forest Reserve values of Chlorophyllb ranged from $12.66 \pm 1.68$ to $31.05 \pm 20.14 \mathrm{mg} / 100 \mathrm{~g}$ (Figure 6). In Table 3, the lowest value of Chlorophyllreserve was in Albizia lebbek tree species also found in 


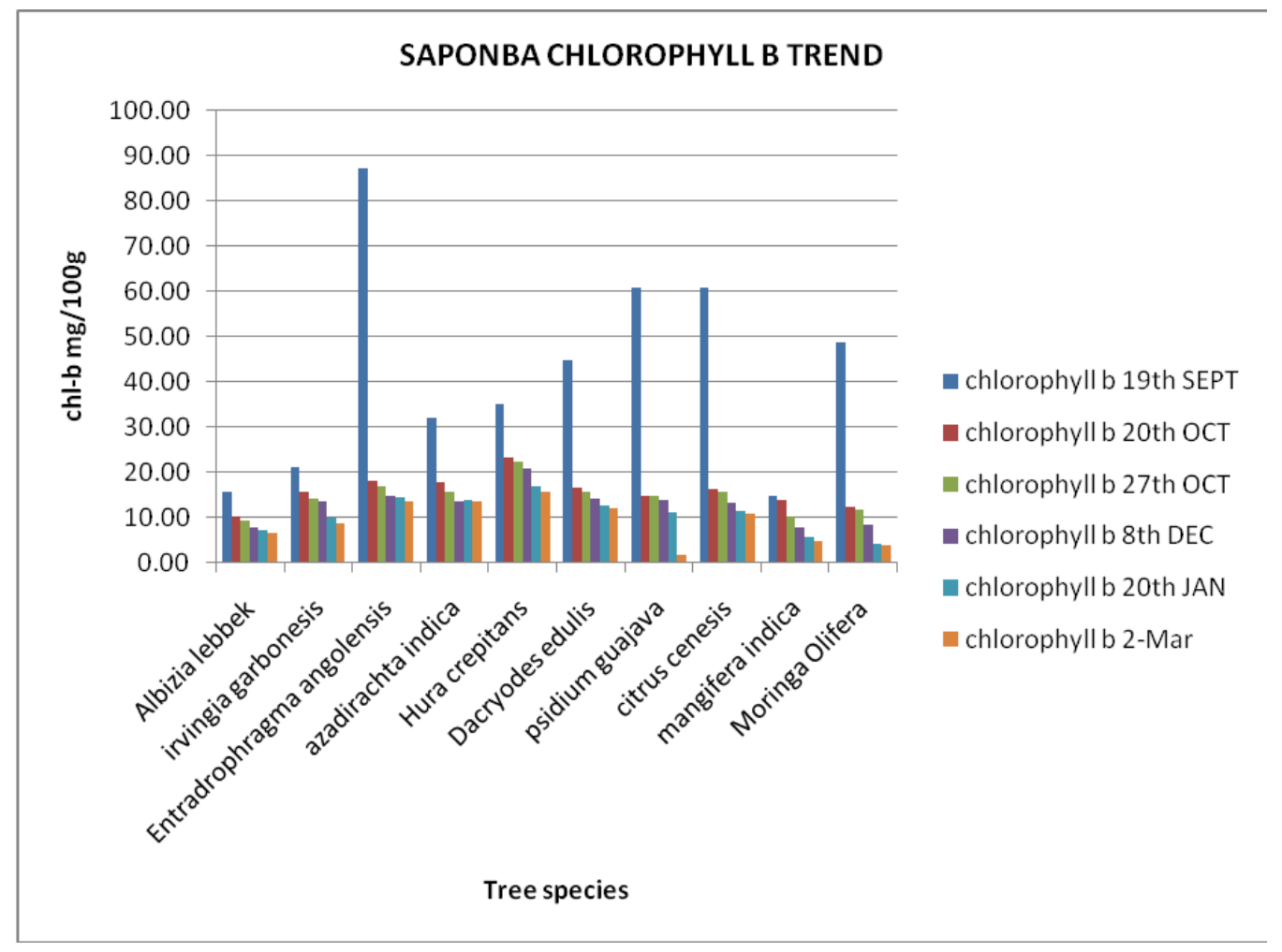

Figure 6. Chlorophyll-b Trend for Saponba Forest Reserve.

Table 3. Chlorophyll-b values during study in the three locations in $\mathrm{mg} / 100 \mathrm{~g}$.

\begin{tabular}{llccc}
\hline S/N & Tree species & Ogba & UNIBEN & Saponba \\
\hline 1 & Albizia lebbek & $23.95 \pm 4.45$ & $10.33 \pm 3.77$ & $31.05 \pm 20.14$ \\
2 & Irvinga garbonesis & $23.31 \pm 4.96$ & $15.10 \pm 4.71$ & $19.44 \pm 18.14$ \\
3 & Entadrophragma angolensis & $38.87 \pm 11.96$ & $33.63 \pm 35.69$ & $28.89 \pm 26.81$ \\
4 & Azadirachta indica & $20.35 \pm 4.97$ & $19.39 \pm 8.72$ & $20.20 \pm 7.79$ \\
5 & Hura crepitans & $41.61 \pm 30.51$ & $24.04 \pm 7.87$ & $28.72 \pm 10.75$ \\
6 & Dacryodes edulis & $46.25 \pm 8.97$ & $22.10 \pm 15.21$ & $20.08 \pm 4.96$ \\
7 & Psidium guajava & $21.39 \pm 4.37$ & $25.13 \pm 23.83$ & $13.42 \pm 3.26$ \\
8 & Citrus cenesis & $45.61 \pm 7.95$ & $25.41 \pm 23.65$ & $14.00 \pm 3.25$ \\
9 & Mangifera indica & $39.61 \pm 21.40$ & $10.56 \pm 4.45$ & $13.38 \pm 2.92$ \\
10 & Moringa Olifera & $20.09 \pm 12.72$ & $18.42 \pm 20.35$ & $12.66 \pm 1.68$ \\
\hline
\end{tabular}

the UNIBEN Forest Reserve. It had a value of $10.33 \pm 3.77$ $\mathrm{mg} / 100 \mathrm{~g}$ and this was due to the amount of automobiles around the UNIBEN Forest Reserve where the tree species is sited. Low chlorophyll content is as a result of more exposure to air pollutants (Agbaire et al., 2016; Giri et al., 2013)

\section{Carotenoids}

Carotenoids variation can be due to internal factors and environmental conditions (Shaikh and Dongare, 2008). As indicated in Table 4, Ogba Forest Reserve had the lowest value of carotenoid from Dacryodes edulis $(6.72 \pm 6.93 \mathrm{mg} / 100 \mathrm{~g})$ and highest was from Hura crepitans with a value of $23.86 \mathrm{mg} / 100 \mathrm{~g}$ (Figure 7 ). In UNIBEN Forest Reserve, the lowest value was obtained from Magnifera indica $(3.10 \pm 0.37 \mathrm{mg} / 100 \mathrm{~g})$ while the highest $(21.73 \pm 15.11 \mathrm{mg} / 100 \mathrm{~g})$ was obtained from Dacryodes edulis species (Figure 8). In saponba Forest Reserve, the lowest value of carotenoids was obtained from Azadiracta indica $(0.04 \pm 2.23 \mathrm{mg} / 100 \mathrm{~g})$ and highest 
Table 4. Carotenoid values during study in the three locations in $\mathrm{mg} / 100 \mathrm{~g}$.

\begin{tabular}{llccc}
\hline S/N & Tree species & Ogba & UNIBEN & Saponba \\
\hline 1 & Albizia lebbek & 0.00 & $15.71 \pm 9.14$ & $2.45 \pm 3.04$ \\
2 & Irvinga garbonesis & 0.00 & $8.00 \pm 12.38$ & $4.42 \pm 6.89$ \\
3 & Entadrophragma angolensis & 0.00 & $20.59 \pm 39.48$ & $0.04 \pm 2.23$ \\
4 & Azadirachta indica & 0.00 & $10.56 \pm 19.58$ & 0.00 \\
5 & Hura crepitans & $23.86 \pm 7.84$ & $14.03 \pm 16.29$ & $3.43 \pm 3.01$ \\
6 & Dacryodes edulis & $6.72 \pm 6.93$ & $21.73 \pm 15.11$ & $1.14 \pm 3.89$ \\
7 & Psidium guajava & $8.09 \pm 6.58$ & $18.41 \pm 35.87$ & $0.82 \pm 0.79$ \\
8 & Citrus cenesis & $13.17 \pm 7.93$ & $13.29 \pm 23.64$ & 0.00 \\
9 & Mangifera indica & $10.82 \pm 5.26$ & $3.10 \pm 0.37$ & $11.17 \pm 3.20$ \\
10 & Moringa Olifera & $18.55 \pm 18.17$ & $18.70 \pm 11.18$ & $6.88 \pm 3.53$ \\
\hline
\end{tabular}

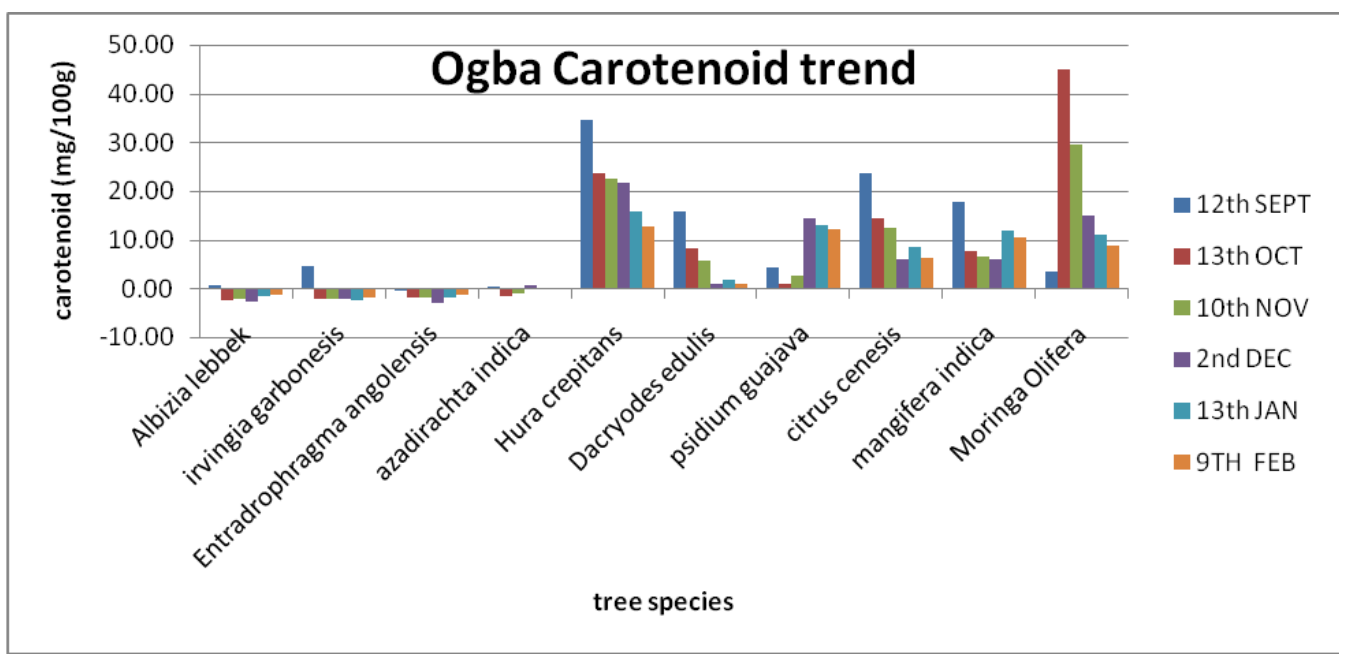

Figure 7. Carotenoid Trend for Ogba Forest Reserve.

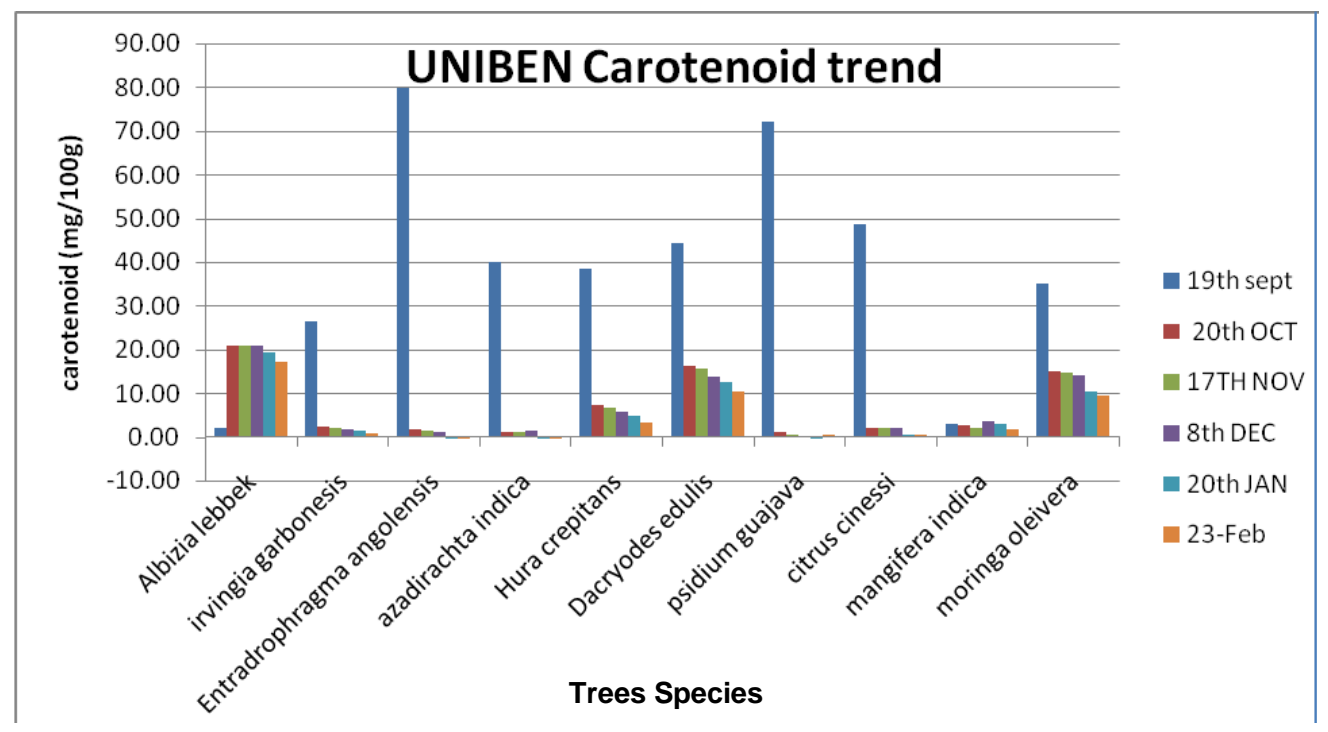

Figure 8. Carotenoid Trend for UNIBEN Forest Reserve. 


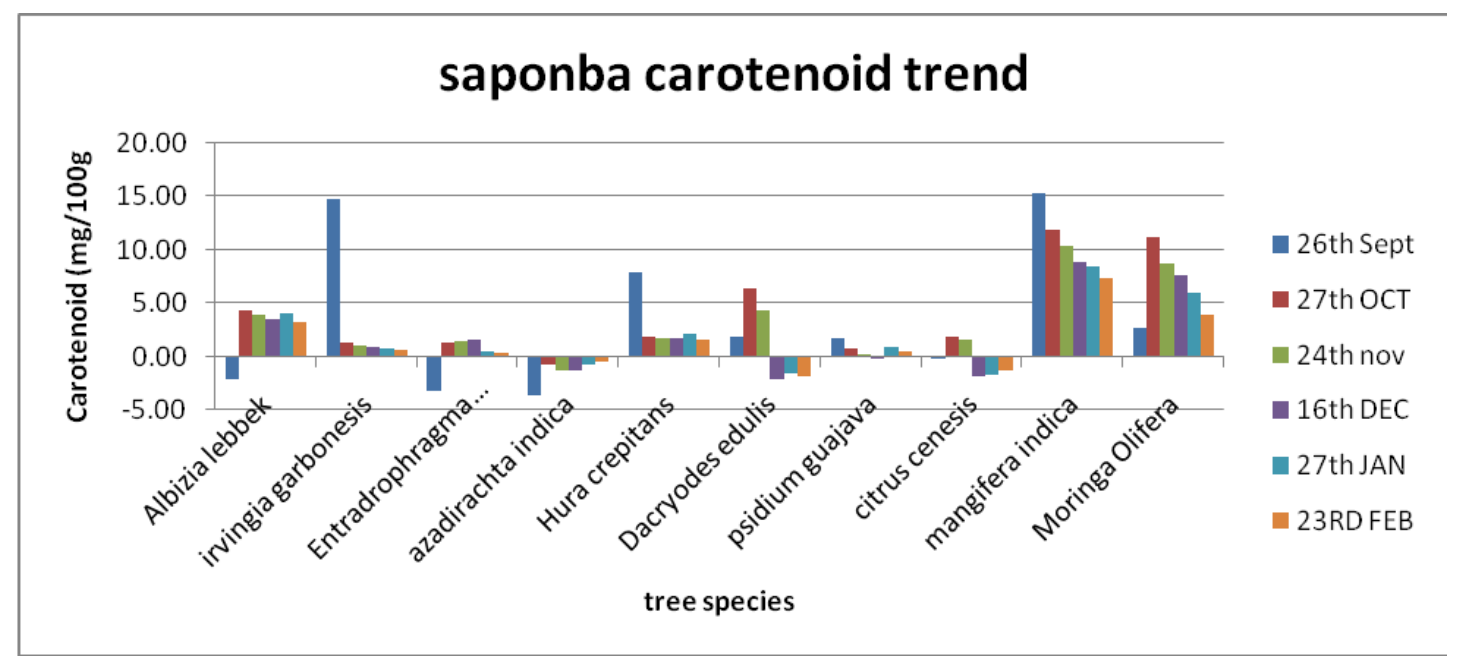

Figure 9. Carotenoid trend for Saponba Forest Reserve.

Table 5. Anova results for the study period.

\begin{tabular}{|c|c|c|c|c|c|c|}
\hline Parameters & Groups & Sum of Squares & df & Mean Square & $\mathbf{F}$ & Sig. \\
\hline \multirow{3}{*}{ Chlorophyll-a } & Between Groups & 139.819 & 2 & 69.909 & 2.597 & $0.093^{a}$ \\
\hline & Within Groups & 726.814 & 27 & 26.919 & & \\
\hline & Total & 866.632 & 29 & & & \\
\hline \multirow{3}{*}{ Chlorophyll-b } & Between Groups & 929.547 & 2 & 464.774 & 6.151 & $0.006^{b}$ \\
\hline & Within Groups & 2040.205 & 27 & 75.563 & & \\
\hline & Total & 2969.752 & 29 & & & \\
\hline \multirow{3}{*}{ Carotenoid } & Between Groups & 675.677 & 2 & 337.838 & 7.799 & $0.002^{c}$ \\
\hline & Within Groups & 1169.518 & 27 & 43.315 & & \\
\hline & Total & 1845.194 & 29 & & & \\
\hline
\end{tabular}

a,b,c mean values on the same column are statistically different.

was from Magnifera indica with a value of $11.17 \pm 3.20$ $\mathrm{mg} / 100 \mathrm{~g}$ (Figure 9). Ogba Forest Reserve recorded very low values of carotenoids when compared to what was recorded by other previous researchers (Mate and Deshmukh, 2016; Marcelo et al., 2012; Tiwari et al., 2006; Tripathy and Gautam, 2007). This indicates severe air pollution in the forest reserve due to the high level of automobiles passing through that area.

Table 5 represented the ANOVA results for Chlorophyll-a, Chlorophyll-b and Carotenoid analyzed for in this study. Statistically it revealed that there were significant differences in the means of Chlorophyll-a, Chlorophyll-b and Carotenoid.

\section{Conclusion}

On the basis of reported values of Tables 2, 3 and 4, the plants investigated in the three selected forest reserves revealed that some tree species had high chlorophyll pigment content which shows that such trees are hardly affected by air pollution in the selected forest reserves. It is however recommended that such trees be suggested as afforestation trees in parts of these artificial forest reserves that have being encroached.

\section{CONFLICT OF INTEREST}

The authors declare that they have no conflict of interest.

\section{REFERENCES}

Agbaire, P. O., \& Esiefarienrhe, E. (2009). Air pollution tolerance indices (APTI) of some plants around Otorogun 
Gas Plant in Delta State, Nigeria. Journal of Applied Science Environmental Management. 13, 11-14.

Agbaire, P. O., Ogboru,R. O., \& Akporhonor, E. E. (2016). Assessment of the Effect of Ambient air quality on some biochemical parameters in Edo State, Niger-Delta, Nigeria. Asian Journal of Applied Sciences, 4(3), 696-703.

Anatoly, A. G., Yoav, Z., Olga, B. C., \& Mark, N. M. (2002). Assesing carotenoid content in plant leaves with reflectance spectroscopy. Photochemistry and Photobiology, 75(3), 272281.

Anamaria, M. (2015). Chlorophyll and Crotenoid content in lettuce and Nettle leaves. Ecotoxicologie, 14, 243-248

Mate, A. R., \& Deshmukh, R. R. (2016). Analysis of effects of air pollution on chlorophyll, water, carotenoid and anthocyanin content of tree leaves using spectral indices. International Journal of Engineering Science and Computing, 6(5), 54655473.

Cuttris, A. J., Abby, J., Caazzonelli, C., Wurtyel, E. T., \& Pogsons, B (2011). Carotenoids. Australian National University Libarian Research Publictions. P 25-26

Dash, J., \& Curran, P. J. (2004). The MERIS terrestrial chlorophyll index. International Journal of Remote Sensing 25, 5003-5013.

David, L. (2009). CRC Handbook of Chemistry and Physics. (90th ed.). Boca Raton, Florida: CRC Press.

Gross, J. (1991). Pigments in vegetables: Chlorophyll and Carotenoids. Van Nostrand Rienhold, New York. Pp. 45-237.

Iqbal, M. Z., Shafig, S., Qamar, Z., \& Athar, M. (2015). Effect of automobile pollution on Chlorophyll content of roadside urban trees. Global Journal Environmental Science management, 1(4), 283-296.

Joshi, P. C \& Swami, A. (2009). Air pollution induced changes in the photosynthetic pigments of selected plant species. Journal of Environmental Biology, 30(2), 295-298.

Jenson, A. (1978). Chlorophyll and Carotenoids. In: Hand book of phycological Methods. Hellebust, J. A., and Craigie, J. S. (eds.). Cambridge University Press, London. Pp. 59-70

Kapoor, C. S., \& Chittora, A. K. (2016). Efficent control of air pollution through plants a cost effective alternatives. Journal of Climatology and Weather Forcasting. 4, 184

Kousar, H., Kumar, N., Pavithra, K., \& Patel, A. M. (2014). Analysis of biochemical parameters as Tolerance index of certain chosen plant species of Bhadravathi town". International Journal of Environmental Sciences, 3, 11-16.

Larcher, W. (1995). Physiological plant ecology, Berlin Springer. Pp. 121-123.

Lichtenthaler, H. K. (1985). Chlorophylls and carotenoids: pigments of photosynthetic biomembranes. Methods Enzymol, 148, 350-382.

Lisiewska, Z., Waldemar, K., \& Anna, K. (2006). Content of Vitamin C, Caroenoid, Chlorophylls and Polyphenols in green parts of Dill (Anethium graveolens L.) depending on Plant height. Journal of Food Composition and Analysis. 19, 134140.

Lisiewska, Z., S"upski, J., \& Korus, A., (2001). Influence of cultivation period, cultivar and usable part on content of chlorophylls and volatile oils in dill (Anethum graveolens L.). Electronic Journal of Polish Agricultural Universites. http://www.ejpau.media.pl/articles/volume4/issue2/food/art18.pdf.
Marcelo, F. P., Suele, C. F., Marcel, T., Marco, S., \& Eugenia, C. P. (2012). Spectrophotometric determination of Chloroplastidic pigments in acetone, ethanol and dimethylsulphoxide. Brazillian Journal of Biosciences. 11(1), 52-58.

Merzlyak, M. N., \& Gitelson, A. A. (1995). Why and what for the leaves are yellow in autumn? On the interpretation of optical spectra of senescing leaves (Acer platanoides L.) Journal of Plant Physiology 145, 315-320.

Nayek, S., Choudhury, J. H., Jaishee, N., \& Roy, S. (2014). Spectrophotometric analysis of chlorophylls and carotenoids from commonly grown fern species by using various extracting solvent. Research Journal of Chemical Science. 4(9), 63-69.

Nichiporovich, A. A. (1974). Chlorophyll and Photosynthetic productivity in plants. Shlyk, A. A., (ed.), Minsk: Nauka I Tekhnika. Pp. 49-62.

Penuelas, J., Filella, I., Biel, C., Serrano, L., \& Save, R. (1993). The reflectance at the $950-970 \mathrm{~nm}$ region as an indicator of plant water status. International Journal of Remote Sensing, 14, 1887-1905

Raza, S. H., \& Murthy, M. S. R. (1998). Air pollution Tolerance Index of Certain Plants of Nacharam Industrial Area, Hyderabad. Indian Journal of Botany, 11(1), 91-95.

Shaikh S. D., \& Dongare, M. (2008). Analysis of photosynthesis pigments in Adiantum lunulatum Burm at different localities of Sindhudurg District (Maharastra). Indian Fern J., 25, 83-86.

Shiragave, D. D., Ramteke, A. A., \& Patil, S. D. (2015). Plant responses to vehicular pollution: specific effect on photosynthetic pigments of plants at divider of $\mathrm{NH}-4$ highway Nipani Area, Karnataka State, India. Central European Journal of Experimental Biology, 4(2), 1-4.

Sims, D. A., \& Gamon, J. A. (2002). Relationship between leaf pigment content and spectra reflectance across a wide range species, leaf structures and development stages. Remote Sensing Environment, 18, 337-354.

Giri, S., Shrivastava, D., Deshmukh, K., \& Dubey, P. (2013). Effect of air pollution on chlorophyll content of leaves. Current Agriculture Research Journal, 1(2), 93-98.

Tripathi, A. K., \& Gautam, M. (2007). Biochemical parameters of plants as indicators of air pollution. Journal of Environmental Biology, 28(1), 127-132.

Vicas, S. I., Laslo, V., Pantea, S., \& Bandict, G. E. (2010). Chlorophyll and carotenoids pigments from Mistletoe (Viscum album) leaves using different solvents, Fascicula Biology., 2, 213-218.

Wellburn, A. R. (1994). The spectral determination of chlorophylls $\mathrm{a}$ and $\mathrm{b}$, as well as total carotenoids, using various solvents with spectrophotometers of different resolution. Journal of plant physiology, 144(3), 307-313. 